\title{
Hepatitis B and C Virus Infection and Cholangiocarcinoma: A Case-Control Study in Turkey
}

\author{
Ibrahim K. ONAL ${ }^{1}$, Erkan PARLAK ${ }^{1}$, Murat KEKILLI ${ }^{1}$, Mevlut KURT ${ }^{1}$, Habibe ALIOGLU ${ }^{2}$, \\ Selcuk DISIBEYAZ ${ }^{1}$, Abdurrahim SAYILIR ${ }^{1}$, Yavuz BEYAZIT ${ }^{1}$, Nurgul SASMAZ ${ }^{1}$ \\ ${ }^{1}$ Turkiye Yuksek Ihtisas Training and Research Hospital, Department of Gastroenterology \\ ${ }^{2}$ Turkiye Yuksek Ihtisas Training and Research Hospital, Department of Cardiology, Ankara, TURKEY
}

\begin{abstract}
Hepatitis B and C virus (HBV and HCV) infection have been proposed as risk factors for cholangiocarcinoma, but the results are inconsistent through different reports. This study is to carry out a hospital-based case-control study to investigate the association between HBV and HCV infection and cholangiocarcinoma in Turkey. A total of 127 cases and 48 matched controls were included in the study. There were 89 cases with extrahepatic cholangiocarcinoma, 10 cases with intrahepatic cholangiocarcinoma and 28 cases with gallbladder cancer. The patients and controls were questioned on smoking, alcohol drinking, history of cholecystolithiasis, choledocholithiasis and hepatolithiasis. Blood from all participants were tested for HBsAg, Anti-HBs, Anti-HBc lgG and Anti-HCV. The prevalence of smoking, alcohol drinking, cholecystolithiasis, choledocolithiasis, hepatolithiasis, anti-HCV, HBsAg and anti$\mathrm{HBs} / \mathrm{anti}-\mathrm{HbclgG}$ did not differ significantly between the patients and controls ( $p>0.05$ ). In the subgroup analysis there was no significantly more prevalent risk factor except smoking in intrahepatic cholangiocarcinoma ( $p=0.019)$. In conclusion, HBV or HCV infection were not found to be risk factors for development of CC in this study.
\end{abstract}

Keywords: Cholangiocarcinoma, Hepatitis B, Hepatitis C

\section{ÖZET}

Hepatit B ve C Virüs Enfeksiyonu ve Kolanjiokarsinom: Türkiye'de Bir Vaka-Kontrol Çalışması

Hepatit B ve C virüsü (HBV ve HCV) enfeksiyonu, kolanjiokarsinom için risk faktörleri olarak öne sürülse de, farklı raporlarda sonuçlar tutarsızdır. Bu çalışmada Türkiye'de HBV ve HCV enfeksiyonu ve kolanjiokarsinom arasındaki ilişkiyi araştırmak için hastane tabanlı bir vaka-kontrol çalışması yürütülmüştür. Toplam 127 vaka ve 48 sağlıklı kontrol çalıșmaya alındı. 89 olguda ekstrahepatik kolanjiokarsinom, 10 olguda intrahepatik kolanjiokarsinom ve 28 olguda safra kesesi kanseri vardı. Hasta ve kontrol grubundakiler sigara, alkol kullanımı, kolesistolitiazis, koledokolitiazis ve hepatolitiazis için sorgulandı. Tüm katılımcıarın kanları HBsAg, Anti-HBs, Anti-HBc lgG ve Anti-HCV için test edildi. Hasta ve kontrol grubu arasında sigara, alkol kullanımı, kolesistolitiazis, koledokolitiazis ve hepatolitiazis, anti-HCV, HBsAg ve anti-HBs/anti-HbclgG prevelansı açısından anlamlı fark yoktu ( $p>0.05$ ). Alt grup analizinde intrahepatik kolanjiokarsinomda sigara dışında ( $p=0.019)$ hiçbiri anlamlı risk faktörü olarak görülmedi. çalışmamızda HBV ve HCV enfeksiyonları, kolanjiokarsinom gelişimi için risk faktörü olarak saptanmamıştır.

Anahtar Kelimeler: Kolanjiokarsinom, Hepatit B, Hepatit C 


\section{INTRODUCTION}

Cholangiocarcinoma (CC) is the primary cancer of the epithelial cells in the bile ducts. The term was originally referred only to primary tumors of the intrahepatic bile ducts but it is now regarded as inclusive of intrahepatic, perihilar, and distal extrahepatic tumors. ${ }^{1}$ About $50-60 \%$ of tumors occur at the bifurcation of the left and right hepatic ducts (hilar cholangiocarcinoma, 'Klatskin' tumor), $10 \%$ are intrahepatic and $20-30 \%$ are extrahepatic distal bile duct tumors. Cholangiocarcinomas comprise only $3 \%$ of gastrointestinal tumors; however, they are the second most common primary hepatic tumors, and their incidence is increasing. ${ }^{2}$ Surgery, either segmental hepatic resection or liver transplantation, offers the only hope for cure, but cannot typically be offered. There is no effective medical therapy. Gallbladder carcinoma is the sixth most common carcinoma of the digestive tract and the most common carcinoma of the biliary tree. ${ }^{3}$ Although surgical resection has offered improvement in the overall survival most patients still present with advanced disease that is not amenable to cure.

Risk factors for CC include age (over 65 years old), primary sclerosing cholangitis, chronic intraductal gall stones, bile duct adenoma and biliary papillomatosis, Caroli's disease, choledochal cysts, thorotrast, smoking, liver flukes (Opisthorchis viverrini and Clonorchis sinensis), chronic typhoid carrier state. ${ }^{1}$ Risk factors for gallbladder cancer are cholelithiasis, calcified gallbladder, long common channel formed by the pancreaticobiliary malunion, large polyps $(>1 \mathrm{~cm})$, chronic typhoid carrier state and primary sclerosing cholangitis. ${ }^{4,5}$ Although hepatitis $\mathrm{B}$ and $\mathrm{C}$ virus (HBV and $\mathrm{HCV}$ ) infection have been proposed as risk factors for $\mathrm{CC}$ the results are inconsistent through different studies. ${ }^{6} \mathrm{We}$ aimed to assess the association between these infections and biliary tract cancer, in a case-control study in Turkey, a low risk population.

\section{MATERIALS AND METHODS}

Cases were selected from newly diagnosed consecutive CC and gallbladder cancer inpatients admitted to the Turkiye Yuksek Ihtisas Teaching and Research Hospital from January 2006 to August 2010. Diagnosis of CC was confirmed histologically in 19 out of 89 patients $(21.4 \%)$ with extrahepatic tumor (ECC), 18 out of 28 patients $(64.3 \%)$ with gallbladder cancer and in all of 10 patients $(100 \%)$ with intrahepatic tumor (ICC). The other cases could be diagnosed non-histologically using combination of ultrasonography, computerized tomography, endoscopic retrograde cholangiopancreatography (ERCP), magnetic resonance cholangiopancreatography (MRCP) and measurement of CA 19-9 levels. The diagnosis of ECC was made non-histologically only if no other primary tumor was detected after careful search. The control group consisted of 48 patients who were unaffected by liver diseases. They were selected from patients who admitted to the Department of Cardiology. The cases were matched to controls in terms of age ( \pm 5 years) and sex. The patients and controls were questioned on smoking, alcohol drinking, history of cholecystolithiasis, choledocholithiasis and hepatolithiasis. For both cases and controls, ever having smoked cigarettes was defined as having smoked cigarettes $\geq 6$ $\mathrm{d} /$ wk for $\geq 6 \mathrm{mo}$, and ever having drunk alcohol as having consumed alcoholic beverages $\geq 3 \mathrm{~d} /$ wk for $\geq 6$ mo. All patients with $\mathrm{CC}$ had been examined for the signs of cirrhosis. In addition, pathological assessments and computed tomography scans of all of the patients were reviewed for evidence of cirrhosis.

Blood samples were taken from all patients and controls on the first day of hospital admission, and tested for hepatitis B surface antigen (HBs), surface antibody (Anti-HBs), core antibody of IgG type (Anti-HBc IgG) and hepatitis $\mathrm{C}$ antibody (Anti$\mathrm{HCV}$ ) using a commercial ELISA (Abbott , North Chicago, IL, USA). There was no previous history of hepatitis B vaccination in patients and controls. Serum CA 19-9 concentrations were measured in patients with chemiluminescent enzyme immunoassay methods in serum and bile samples by using immulite GI-MA commercial kit (DPC(r), Los Angeles). The project was approved by the local Ethics Committee (Reference number B.10.4.ISM.4. 06.00.15-PER.SB-722.04).

Categorical variables were compared using the $\chi^{2}$ test and continuous variables were compared using Student's t test. Odds ratio (OR) and $95 \%$ confidence intervals (CI) were calculated using a logistic regression model. $\mathrm{P}<0.05$ was considered statisti- 
cally significant. These analyses were performed using SPSS 18.0 software (SPSS, Chicago, IL, USA).

\section{RESULTS}

There was no case with cirrhosis in the patient group. The prevalence of smoking, alcohol drinking, cholecystolithiasis, choledocolithiasis, hepatolithiasis, anti-HCV, HBsAg and anti-HBs/anti-HbcIgG did not differ significantly between histologically and non-histologically diagnosed cases ( $p>0.05$ ). In the patient group the frequency of risk factors and demographic variables were not significantly different from the controls $(p>0.05)$ (Table 1). In the subgroup analysis there was no significantly more prevalent risk factor except smoking in ICC (Table 2 and 3). Logistic regression analysis was performed to determine factors possibly associated with cholangiocarcinoma. No correlation could be established between cholangiocarcinoma and age, sex, smoking, alcohol drinking, cholecystolithiasis, and HBsAg (Table 4).

\section{DISCUSSION}

HBV and HCV are established risk factors for hepatocellular carcinoma and it has been suggested that they may have a role in cholangiocarcinogene- sis. ${ }^{7}$ In a Korean case control study, $13 \%$ of CC cases were found positive for anti-HCV and $14 \%$ for $\mathrm{HBV}$ surface antigen (HBsAg), compared to $4 \%$ and $2 \%$ of controls, respectively. ${ }^{8}$ Tao LY et al showed that ICC patients had a significantly higher prevalence of HBsAg (27.9 vs. $5.0 \%)$ and anti-HBc (without $\mathrm{HBsAg}$ ) (50.8 vs. $37.6 \%$ ) than did controls but HBV markers were not significantly different between the ECC cases and the controls. ${ }^{9}$ In another Chinese case control study ICC patients had a higher prevalence of HBsAg seropositivity (48.4\% vs $9.6 \%)$ but not anti-HCV positiviy. In a population based case control study including 535 ICC and 549 ECC cases HCV infection was associated with ICC, but not ECC..$^{10}$ The precise mechanism of HBV or HCV infection in the carcinogenesis of ICC is unknown. Wang et al observed frequent, strong HBX immunochemical staining in bile duct cells of cancerous and surrounding hepatic tissues, in some HBV-infected ICC specimens, and suggested that HBX may contribute to the pathogenesis of ICC. ${ }^{11} \mathrm{HBX}$ may also activate the transcriptional expression of human telomerase reverse transcriptase, which leads to tumorigenesis in cholangiocytes. ${ }^{12} \mathrm{HCV}$ RNA has been isolated from cholangiocarcinoma tissue and $\mathrm{HCV}$ has been shown to cause bile duct epithelial cell injury. ${ }^{13,14}$ Similar to HCV related-HCC, the increased risk of ICC in patients with $\mathrm{HCV}$ may result from $\mathrm{HCV}$ -

\begin{tabular}{|c|c|c|c|}
\hline & Controls $n=48(\%)$ & Patients $n=127(\%)$ & $P$ value \\
\hline Age & $64.6 \pm 7.4$ & $65.3 \pm 11.7$ & 0.648 \\
\hline Male/Female & $25 / 23$ & $63 / 64$ & 0.770 \\
\hline $\mathrm{HBsAg}^{+}$ & $3(6.3)$ & $3(2.4)$ & 0.207 \\
\hline Positive for at least one HBV marker ${ }^{8}$ & 28 (58.3) & 78 (63.4 ) & 0.538 \\
\hline Anti-HCV ${ }^{+}$ & $1(2.1)$ & $1(0.8)$ & 0.472 \\
\hline Cholecystolithiasis & $8(16.7)$ & $12(9.4)$ & 0.181 \\
\hline Hepatolithiasis & - & $2(1.6)$ & 0.382 \\
\hline Choledocholithiasis & - & $1(0.8)$ & 0.542 \\
\hline Smoking & $11(22.9)$ & $42(33.3 \%)$ & 0.182 \\
\hline Alcohol drinking & $1(2.1)$ & $9(7.1 \%)$ & 0.203 \\
\hline
\end{tabular}




\begin{tabular}{|c|c|c|c|}
\hline & Controls $n=48(\%)$ & Gallbladder Cancer $n=28(\%)$ & $P$ value \\
\hline Age & $64.6 \pm 7.4$ & $63.0 \pm 10.7$ & 0.487 \\
\hline Male/Female & $25 / 23$ & $5 / 23$ & 0.003 \\
\hline $\mathrm{HBsAg}^{+}$ & $3(6.3)$ & $1(3.6)$ & 0.614 \\
\hline Positive for at least one HBV marker ${ }^{8}$ & $28(58.3)$ & $18(66.7)$ & 0.477 \\
\hline Anti-HCV ${ }^{+}$ & $1(2.1)$ & 0 & 0.442 \\
\hline Cholecystolithiasis & $8(16.7)$ & $1(3.6)$ & 0.088 \\
\hline Smoking & $11(22.9)$ & $4(14.8)$ & 0.400 \\
\hline Alcohol drinking & $1(2.1)$ & $1(3.6)$ & 0.696 \\
\hline
\end{tabular}

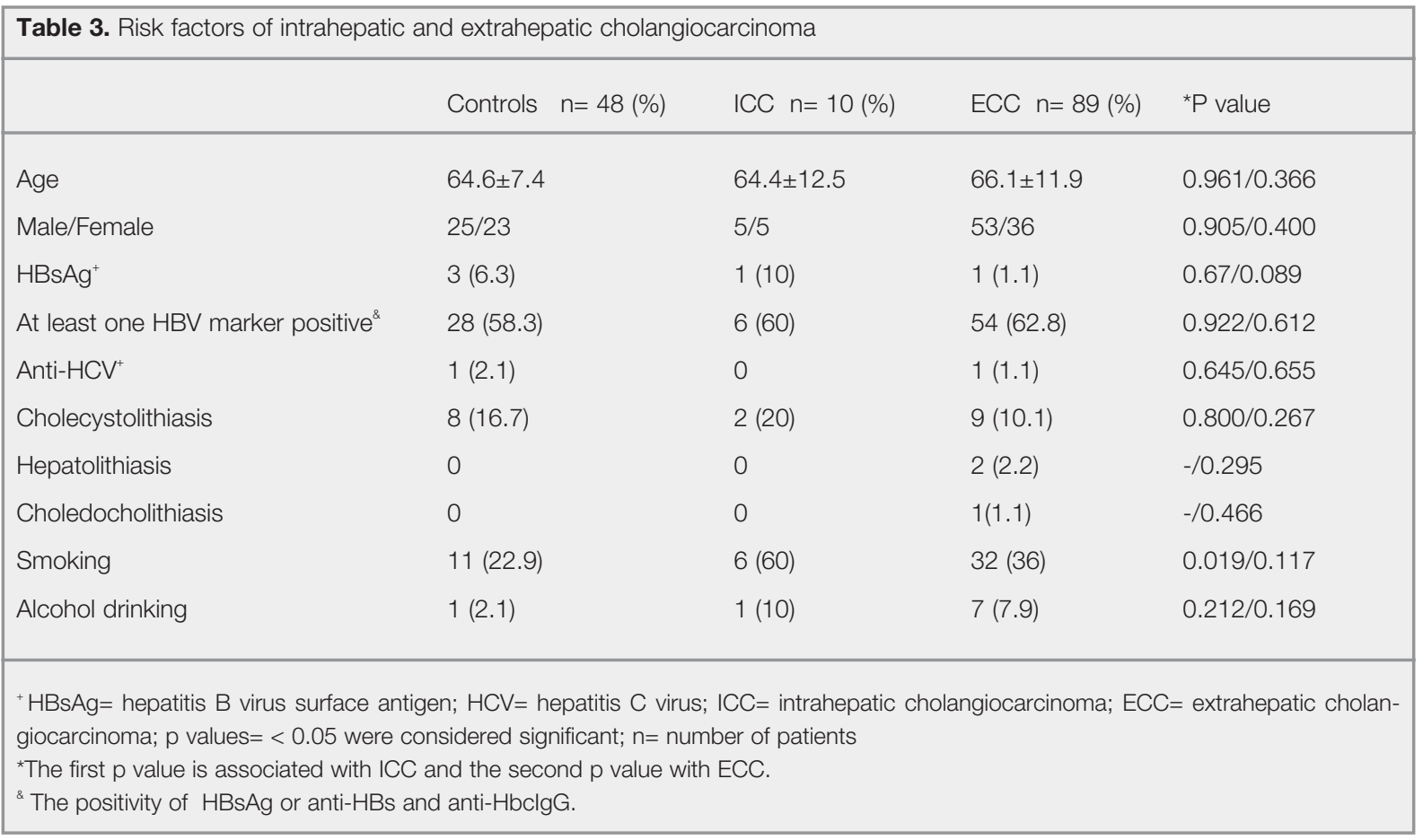

associated chronic liver damage. The relative risks of infection with HBV or HCV for the development of ICC and ECC vary widely according to the prevalence of each viral infection and are inconsistent in their significance through different studies. This may partially explain that neither $\mathrm{HBV}$ nor $\mathrm{HCV}$ was associated with $\mathrm{CC}$ in our series. Another factor that may have influenced our results is the low number of ICC cases in our series. But our findings, the conflicting results of the various studies and the absence of a widely accepted hypothesis support the idea that HBV or HCV infection can not yet be accepted as strong risk factors for $\mathrm{CC}$.

Smoking was associated with ICC in our series and this finding was observed in several other studies. ${ }^{10,15}$ Hepatolithiasis is endemic in some parts of Asia and has consistently been associated with ICC because of inflammation and epithelial proliferation. ${ }^{16}$ On the other hand it is uncommon in the West. We had only one case with hepatolithiasis and ICC so we could not confirm this relationship. 


\begin{tabular}{|llll|}
\hline $\begin{array}{l}\text { Table 4. Multivariate logistic regression analysis for Cholan- } \\
\text { giocarcinoma. }\end{array}$ & & \\
\hline & Odds ratio & $95 \% \mathrm{Cl}$ & $\mathrm{p}$ \\
\hline Age & 1.00 & $0.97-1.04$ & 0.69 \\
Sex (Male vs Female) & 0.59 & $0.27-1.29$ & 0.18 \\
HBsAg & 0.38 & $0.07-2.06$ & 0.26 \\
Cholecystolithiasis & 0.48 & $0.18-1.30$ & 0.15 \\
Smoking & 1.99 & $0.81-4.89$ & 0.13 \\
Alcohol drinking & 3.19 & $0.37-27.6$ & 0.29 \\
\hline
\end{tabular}

The most important limitation of our study is the relatively low number of patients which causes some difficulties in the subgroup analysis. This results from the fact that Turkey is a low risk population for biliary tract cancer. On the other hand our series is the only one in Turkey which gives some local information about the risk factors for CC. Increasing the number of patients in the future would provide more clear data.

In conclusion, $\mathrm{HBV}$ or $\mathrm{HCV}$ infection were not found to be risk factors for development of $\mathrm{CC}$ in this study. miology, risk factors, and pathogenesis of cholangiocarcinoma. HPB 10: 77-82, 2008.

8. Shin HR, Lee CU, Park HJ, et al. Hepatitis B and C virus, Clonorchis sinensis for the risk of liver cancer: a case-control study in Pusan, Korea. Int $\mathrm{J}$ Epidemiol 25: 933-940, 1996.

9. Tao LY, He XD, Qu Q, et al. Risk factors for intrahepatic and extrahepatic cholangiocarcinoma: a case-control study in China. Liver Int 30: 215-221, 2010.

10. Welzel TM, Graubard BI, El-Serag HB, et al. Risk factors for intra- and extrahepatic cholangiocarcinoma in the United States: a population based case-control study. Clin Gastroenterol Hepatol 5: 1221-1228, 2007.

11. Wang WL, London WT, Feitelson MA. Hepatitis $B \times$ antigen in hepatitis $B$ virus carrier patients with liver cancer. Cancer Res 51: 4971-4977, 1991.

12. Zou SQ, Qu ZL, Li ZF, Wang X. Hepatitis B virus X gene induces human telomerase reverse transcriptase mRNA expression in cultured normal human cholangiocytes. World J Gastroenterol 10: 2259-2262, 2004.

13. Yin F, Chen B. Detection of hepatitis $C$ virus RNA sequences in hepatic portal cholangiocarcinoma tissue by reverse transcription polymerase chain reaction. Chin Med J (Engl) 111: 1068-1070, 1998.

14. Ahrendt SA, Nakeeb A, Pitt HA. Cholangiocarcinoma. Clin Liver Dis 5: 191-218, 2001.

15. Shaib YH, El-Serag HB, Davila JA, et al. Risk factors of intrahepatic cholangiocarcinoma in the United States: a case-control study. Gastroenterology 128: 620-626, 2005.

16. Kubo S, Kinoshita H, Hirohashi K, Hamba H. Hepatolithiasis associated with cholangiocarcinoma. World $\mathrm{J}$ Surg 19: 637-641, 1995.

\section{Correspondence:}

Dr. Mevlut KURT

Türkiye Yüksek intisas Hastanesi

Gastroenteroloji Bölümü

Kizlay Sk. No: 2

06100, Sinhiye, ANKAR / TURKEY

Tel: (+90.505) 2762812

Fax: (+90.312) 3124120

E-mail: dr.mevlutkurt@gmail.com evaluation, staging, and treatment options. AJR Am J Roentgenol 191: 1440-1447, 2008.

6. Shin HR, Oh JK, Masuyer E, et al. Epidemiology of cholangiocarcinoma: An update focusing on risk factors. Cancer Sci 101: 579-585, 2010.

7. Khan SA, Toledano MB, Taylor-Robinson SD. Epide- 